\title{
Állam és jog \\ az ellentétek földjén I. ${ }^{1}$
}

A Közel-Kelet és az iszlám joga

\section{State and Law on Land of Contrasts}

Far East and Islamic Law

\section{Összefoglalás}

Jelen tanulmány célja Jany János Jogi kultúrák Ázsiában címû́ magnum opusának ismertetése és elemzése. Írásunk terjedelmes voltát azon tény indokolja, hogy egy hétszáz oldalas kézikönyv recenziószerú bemutatása még a kötet legjelentôsebb erényeit sem lenne képes kidomborítani. Ugyanakkor szintén értelmetlen volna a mú egy rövidebb kivonatát parafrázisszerúen közreadni, mintegy megcsonkítva azt. Éppen ezért készült terjedelmes végjegyzet a tanulmányhoz, mely kiváltképp példázza saját észrevételeinket. Az elsô rész a Közel-Kelet és az iszlám jogát mutatja be.

Kulcsszavak: ázsiai jog, jogtudósok, keleti kereszténység joga, korai és modern zsidó jog, korai, klasszikus és modern iszlám jog, ókori és modern közel-keleti jog, perzsa jog, ókori keleti jog

Dr. IVÁN DÁNIEL, tanársegéd, Nemzeti Közszolgálati Egyetem, Államtudományi és Közigazgatási Kar, Lốrincz Lajos Közigazgatási Jogi Intézet, doktorandusz hallgató, NKE Közigazgatás-tudományi Doktori Iskola (Ivan.Daniel@uni-nke.hu); Dr. KoI GyUlA, tudományos munkatárs, MTA Társadalomtudományi Kutatóközpont, Jogtudományi Intézet; tudományos fômunkatárs, NKE Államtudományi és Közigazgatási Kar, Lốrincz Lajos Közigazgatási Jogi Intézet (Koi.Gyula@uni-nke.hu). 


\section{Summary}

The main purpose of this study is to present and analyse János Jany's magnum opus entitled Legal Cultures in Asia. The reason of this extensive work of ours is to avoid presenting, such a huge handbook like this, only in a review because it is not possible to highlight at least the most relevant virtues of it. However it would be pointless to publish a brief extract of this piece of work in a paraphrase way as giving a cut version of it. As a consequence, an extensive endnote shall be made to this study which emphasises the primer example of our remarks. The first part deals with Far-East and Islamic law.

Keywords: Asian law, legal scholars, law of Eastern Christianity, early and modern Jewish law; early, classical, and modern Islamic law, ancient and modern law of the Far East, Persian law, law of the ancient Near East

A jogtudományban régtôl fogva alkalmazott, dicséretes hagyomány, hogy egyes kiemelkedô színvonalú munkákat nem egyszerú annotáció vagy könyvismertetés, illetôleg recenzió, továbbá recenziós tanulmány formájában, hanem egyenesen önálló szemlecikk vagy vitacikk keretei között vizsgálnak. Ez a forma különösen az 1945 elốtti idôkben tekinthetô bevettnek, ${ }^{2}$ illetôleg egy-egy késóbbi szórványos példa az adott korszak utáni hét évtizedból is felhozható (akár jelen folyóirat korábbi számaiból) . ${ }^{3}$

Napjainkban az államtudományok és a jogtudomány kutatása körében egyre népszerúbbnek tetszik az ázsiai tematika. Nyilvánvalóan az ázsiai jogok múveléséhez speciális érdeklódésre, sajátos felkészültségre van szükség. Az a mú, amelyrôl szó van (Jany, 2016a), igen ritka és különleges nagymonográfia, amely minden figyelmünket megérdemli. Vállalva azt a veszélyt, hogy értékelésünket jelen anyag szövedékében kissé elôrehozzuk, bátran kijelenthetjük, hogy a világ jogirodalma nem ismer még egy olyan munkát, amely az ázsiai jogi kultúrákat az ókortól gyakorlatilag napjainkig kézikönyvszerúen összefoglalná. Maga a múfaj némi rokonságot mutat a német jogtudományból eredeztethetô Europäische Rechtsgeschichte ${ }^{4}$ múfajával. Kissé leegyszerúsítve, az Europäische Rechtsgeschichte azt jelenti, hogy az adott témával foglalkozó jogtörténész vagy tanszéki kollektíva, illetôleg kutatócsoport tanultságának vagy érdeklôdésének megfelelően tekinti át Európa jogtörténetét. Az áttekintés határai nyilván a szerzôk felkészültségétôl, illetôleg nyelvi kompetenciáitól függ. Éppen ezért alapvetôen az Europäische Rechtsgeschichte alapú jogtörténeti szemlélet fóképpen az Europa occidentalis és alapvetôen Bizánc bemutatására szokott szorítkozni, azon belül is inkább az angolszász, a francia és a német nyelvú területek hangsúlya figyelhetố meg. Nyilván azért alapvetôen nem maradt ki az olasz és spanyol kultúrkör sem, és ideérthetôek még többkevesebb teljességgel a skandináv országok (Svédország és Dánia mindenképpen, míg Izland feltérképezése nem nevezhetô túlzottan gyakori vállalkozásnak). Mindezeken belül a szláv országok, valamint a Magyar Királyság és a románok, illetôleg albánok lakta területek bemutatása mindig a szerzôk igényességén és kompetenciáján múlik. 
Tehát míg az Europäische Rechtsgeschichte múfajnak van egyfajta kialakultnak nevezhetô vizsgálódási köre, addig az ázsiai jogtörténeti tematika már csak a múvek hiánya miatt is erôsen kialakulatlan. Valamelyest megalapozó példaként hivatkozható H. Patrick Glenn alapvetô kézikönyve, amely a világ jogi hagyományait igyekezett egybegyújteni (Glenn, 2000).

A bevezetésben a szerzô, Jany János is utal Glenn munkájára mint inspirációs forrásra, azonban ebben az esetben nem az a folyamat következett be, amit már oly gyakran tapasztalhattunk az ilyesfajta termékenyítô szellemi találkozásokkor, nevezetesen, hogy az angol eredeti valamifajta hazai recepciója tenné ki a munkálkodás eredményét. Sokkal inkább az a kedvezó fordulat tapasztalható, hogy az újonnan keletkezett mú hasznosan kiegészíti az azt inspiráló forrásmúvet, bár arra sem túlzás utalni, hogy a hétszázöt oldal terjedelmú végeredményt tekintve, esetükben ennél jóval többrôl van szó. A szerzô is világossá teszi, hogy Glenn alapvetô kézikönyve a kontinentális és az angolszász jog mellett bemutatja a konfuciánus, a hindu, az iszlám és a zsidó jogi hagyományt is. Ugyanakkor nem egy ázsiai jogi tradíció - példának okáért a buddhista jog vagy a japán jog - kimarad, nem is szólva az ázsiai jogok folytatás nélküli jogi világáról. Jany János nem is titkolja tehát, hogy a fent említett hiányok kiegészítését célozza egy teljes mértékben Ázsiára fókuszáló könyv keretei között.

Érdemes a szerzó életrajzában megmerítkeznünk. Jany János a Piarista Gimnáziumban tett érettségi vizsgát. A középiskolai stúdiumok elvégzése után az Eötvös Loránd Tudományegyetem Állam- és Jogtudományi Karán folytatta tanulmányait, itt 1992-ben szerzett summa cum laude minôsítésú diplomát jogász szakon. Az Eötvös Loránd Tudományegyetem Bölcsészettudományi Kar iranisztika szakán végzett tanulmányait 1996-ban fejezte be kiváló minôsítésú diplomával. Külföldi tanulmányokat folytatott Berlinben, Bostonban, valamint Teheránban.

Iranisztikából (nyelv- és irodalomtudományok) 2001-ben, állam- és jogtudományokból 2008-ban szerzett summa cum laude minôsítésú PhD-fokozatot. Kutatási területei közé tartozik elsôsorban a Közel-Kelet, azon belül fôként Irán jogtörténete, valamint a keleti jogi kultúrák összehasonlító elemzése. A Pázmány Péter Tudományegyetem Bölcsészettudományi Karán megalakulása óta a Nemzetközi Tanulmányok Tanszék vezetôje. Az MTA IX. Osztály köztestületi tagja, az International Political Science Association, valamint a Comparative Judicial Studies Research Committee tudományos tagja.

Fontos szólni a munkásság eddigi publikációs irányairól is. Mintegy 80 értékes publikációjának 10\%-a monografikus alkotás. E tanulmány keretei között alapvetôen ezek felvillantására nyílik csupán lehetôség. A 2000-es évben látott napvilágot a Szászánida Birodalom magánjogáról szóló könyve (Jany, 2000), valamint egy társszerzôs, szerkesztett médiajogi kézikönyv (Jany-Ilosvai-Bölcskei, 2000). Nagyon figyelemreméltó és hiánypótló 2006-ból a klasszikus iszlám jogról írott, félezer oldalnál is terjedelmesebb nagymonográfiája (Jany, 2006). A bíráskodás ${ }^{5}$ és a szociológia kapcsolatát elemzi 2007-es kötete a zsidó, az iszlám, valamint a zoroasztriánus jogban (Jany, 2007). Egy múhelytanulmánya a zoroasztriánus jogról angol nyelven jelent meg a 2011-es év során (Jany, 2011). 2012-ben a Mítosz és valóság angol verzióban is megjelent az Ashgate 
Kiadónál (Jany, 2012). 2016-ban látott napvilágot jelen könyv (Jany, 2016a) mellett az iszlamizmusról szóló kismonográfia is (Jany, 2016b).

A fenti felsorolásból is kitetszik, hogy jelen vizsgált mú az eddigi munkássága legkiemelkedôbb darabja, nagy ívú és kiérlelt összefoglalás, melynek angol nyelvú kiadása elôkészületben van. Önmagában a kötet jelentôsége megalapozza, hogy az abban foglalt tartalmisággal részletekbe menôen foglalkozzunk, ugyanis egy új tematikájú és új szellemiségú könyvvel van dolgunk.

A kötet bevezetése önmagában is érvényesen és önállóan értelmezhetô formában vázolja fel azokat a problémákat, amelyek egy ilyen monstruózus kötet esetében felmerülhetnek. Az elsố kérdés, mint Ázsiával kapcsolatban nemegyszer, a szemlélet, jelen esetben az ázsiai jogokkal kapcsolatos nézôpont kialakításának kérdése. Itt a szerző előtt több rossz történet, példa is adott volt. Az elsố a 19-20. századi nyugat-európai gyarmatosítók attitúdje, amely a nyugati (tehát a nyugat-európai és észak-amerikai) kultúrfölényt hirdette. Nyilván ehhez hasonlatosan aszimmetrikus a posztkolonialista szemlélet, amely egyoldalúan a korábbi nézet ellen fordult az önmarcangolt lelkiismeret-furdalástól hajtottan. Ezzel szemben Jany könyve a Max Weber-i megértő szociológia módszerére emlékeztetô eljárást teszi meg kötete vezérfonalául. Számol azzal a kérdéssel is, hogy van-e értelme önmagában ázsiai jogtörténetet írni. Itt a korábbiakban általunk már fentebb vázolt Europäische Rechtsgeschichte szellemiségében fogant munkák léte a válasz a kérdésre, illetve annak a ténye, hogy ez a múfaj mára már gyakorlatilag megszokottá vált.

A szerzô önkritikusan arra is rákérdez, hogy egy szerzó képes-e egy olyan sok szálon futó problémát feltárni, amelyet ez a térben és idóben is nagy volumenú ázsiai jogtörténeti projektum jelent. Elsôre távolabbinak látszó, de módszertani problémáit illetôen nagyon is a fentebbi kutatási kérdés vonatkozásában párhuzamot képezô problematika az ázsiai filozófiai rendszerek összefoglaló bemutatásának kérdése. Jany János erre azt a példát hozza, hogy az ilyen irányú kötetek a középkori muszlim misztikusok világától a taoista elképzelésig mindent magukban foglalnak. ${ }^{6}$ Ezen párhuzamok kiemelése mellett is teljességgel helytálló a bevezetô azon megállapítása, hogy a kötet meglehetôsen egyedi és újszerú, hiszen nemhogy magyar nyelven nem született hasonló munka, de külföldön sem íródott ilyen átfogó kontribúció.

A másik felmerülő probléma, hogy képes-e egy ilyen széles spektrumot csupán egyetlen kutató feldolgozni. A helyzet az, hogy valójában ez a kérdés minden összehasonlító (komparatív) tudomány, így az összehasonlító jog, illetve az összehasonlító jogtörténet egyik alapkérdése is. Tiszteletre méltó a szerzô lelkiismeretesen az olvasók elé tárt, e ténnyel kapcsolatos, reflektív belsố vívódása. Nyilván nem lehetséges, hogy egyetlen szerzố minden ázsiai problematikát és valamennyi (valójában több száz) ázsiai nyelvet behatóan és azonos súllyal ismerjen. Helyesen mutat rá, hogy még egy esetleges kutatócsoport alkalmazása sem oldaná meg a kérdést, hiszen jószerével lehetetlen erre alkalmas jogi és orientalisztikai végzettségú szerzőgárdát összeállítani. Már nevezetesen olyat, amely csoportosulás egyaránt hitelesen és kompetensen írna mongol, thai vagy éppenséggel burmai jogról. Nagyon fontos a szerzónek azon meglátása, hogy általában a kutatócsoportok kollektív munkái, tekintettel arra, hogy minden ember egyéniség, nem egységesíthetôek, tehát többnyire a legjobb szándék mellett is elv- 
Iván Dániel - Koi Gyula: Állam és jog az ellentétek földjén I.

ész az az elôny, amely az egyszerzôs múveknél vitathatatlan, azaz az egységes szemlélet, a logikusan felépített érvrendszer, illetve a fejezeteken átívelő problémaérzékenység és az egységes módszertan.

Hozzá kell tenni mindehhez, hogy ha alapvetően nem is az ázsiai jog problémájára építetten, de a magyar szerzók között ismerünk egy alkotót, aki hasonló kérdésekkel nézett szembe. Nevezetesen Hamza Gábor akadémikus fô munkájáról (Az európai magánjog fejlódése) van szó (Hamza, 2002), amely gyakorlatilag az európai középkortól napjainkig valamennyi kontinens esetében feldolgozza a modern magánjogi rendszereket ért római jogi hatásokat. ${ }^{7}$ Szükséges e tárgykörben még Hamza akadémikus Jogösszehasonlitás és antikvitás címú, szintén igen jelentékeny munkájára is utalnunk (Hamza, 1998). A római jognak az európai magánjog fejlódésére gyakorolt hatásait vizsgáló Hamza-mú idóbeli horizontja a Nyugatrómai Birodalom felbomlásától egészen a 2000-es évekig mutat előre. Hasonlóan impozáns Jany János munkájának időbeli kiterjedése, amely a Kr. e. 3. évezred Mezopotámiájának jogától egészen napjaink Ázsiájának jelentôs jogi kultúrájáig terjed. A fentiekben olvasható volt H. Patrick Glenn, illetve Hamza Gábor összehasonlító jogi horizontra vonatkozó koncepciója. Nyilván adódik a kérdés, hogy Ázsia esetében a vizsgált szerzô hogyan építi fel a kínálkozó földrajzi horizontot. Hozzá kell tenni ugyanakkor, hogy a széles idôbeli vizsgálódás miatt ez a felépítmény szükségképpen nem tükrözheti maradéktalanul a jelenkori geográfiai és politikai-földrajzi felfogást.

Maga a nagymonográfia a bevezetésen túl öt részre és tizenöt fejezetre, illetôleg három további egységre tagolódik. A részeket tekintve az elsố a közel-keleti kultúrkört, a második az iszlám jogi kultúrkört, a harmadik az indiai jogi kultúrkört, a negyedik a kínai jogi kultúrkört, míg az ötödik a szokásjogi kultúrákat foglalja magában. A fentebb jelzett három további egység körében foglalnak helyet a következtetések, valamint egy bôséges és rendívül hasznos név- és fogalomtár, illetôleg a felhasznált forrásmúveket tartalmazó irodalom.

A bevezetés körében feldolgozott egyes kérdésekkel fentebb már foglalkoztunk, így azokat külön nem érintjük. Mindenképpen le kell szögezni, hogy az ázsiai fókusz miatt ez a monográfia hiánypótló jellegú, és ezáltal a bevezetésben írt mélyebb gondolatiság magyarázó ereje is sokkal nagyobb, mint az olyan tematikák esetében, amelyek már komolyabb feldolgozottsággal rendelkeznek (példának okáért az Europäische Rechtsgeschichte, a római-germán alapú civil jogi rendszerek, illetve az angolszász típusú jog világának feltárására irányuló munkák tekinthetôek ilyennek). Mint a továbbiakban látni fogjuk, mind az idóbeli, mind a térbeli meghatározottság rendívül széles, és a vizsgálódás szintjei az állami jog-vallási jog-szokásjog trichotómiával írhatók le. Vagyis a hagyományos struktúrák szerepe az ázsiai világban sokkal és okkal jelentôsebb, mint amit az euroatlanti kultúrkörben szokásosnak gondolunk. Ugyanakkor részben vagy egészben ezek a hagyományos struktúrák a joghagyományban (illetve abban is) gyökereznek, és nyilván maga a joghagyomány is táplálkozik esetrôl esetre változóan a vallási hagyományból vagy egyéb társadalmi struktúrából.

Nagyon helyénvaló a szerzó azon elgondolása, hogy szükséges a még mindig uralkodó eurocentrikus világképen felülemelkedni, akkor is, ha az európai diverzitást ter- 
mészetes adottságként, míg az ázsiai viszonyok hasonló bonyolultságát elbizonytalanító jellegúként éljük meg. Valóban igaz, hogy az ázsiai jogokat úgy kell megismernünk, ahogy vannak, és nem pedig úgy, ahogy szeretnénk hogy legyenek. Ha ezt az ázsiai diverzitást egy kicsit tovább boncolgatjuk, akkor azt láthatjuk, hogy az ókori közel-keleti hagyományokkal rendelkezó zsidó jog ugyanúgy ennek a spektrumnak a része, mint a sintoista japán jog, amelyre viszont a kínai jog gyakorolt döntô befolyást. Nem hiábavaló a szerzó azon megelólegezése, hogy ez a két halmaz alig rendelkezik közös metszettel a jogfelfogás vagy a tételes jog szintjén, és csak egyetérteni tudunk azzal, hogy a kölcsönös befolyás lehetôsége valóban aligha vethetô fel. De nyilván ez a számunkra jóval ismerôsebb, legtágabb értelemben vett európai jogi kultúrkörben ${ }^{8}$ is felvethetô, mondjuk példának okáért az albán és az izlandi jog, valamint az észt és a portugál jog vonatkozásában. Tehát Jany János úgy tekinti, hogy nem létezik valamifajta egységes ázsiai jogi kultúra, de számos azonos mentális struktúrából eredôen bizonyos hasonlóságok, esetenként egyezések léteznek, ezek lehetnek átvételek eredményei, illetôleg a hasonló gondolkodásmód is lehet ennek bölcsôje. Elég arra gondolni, hogy Kína - ha eltérô mértékben is, de - befolyást gyakorolt a koreai, a japán, valamint a vietnámi jogi gondolkodásra. A kínai behatást - mint ahogy a szerzố rámutat - a helyi hagyományok árnyalták, akár módosították is, de az alaphelyzetet megszüntetni nem tudták.

Hasonló helyzet játszódott le a hindu jogi kultúra és Délkelet-Ázsia vonatkozásában, ahol a kínai jog Kelet-Ázsiára tett hatásához hasonló folyamat játszódott le. Nyilván az ázsiai jogi kultúra vizsgálata során a 19. századtól kezdôdôen számolnunk kell alapvetôen nyugat-európai, francia és német minták megjelenésével. Ilyen volt a nyugati alkotmányok szószerintiségig menô átvétele, illetve a büntetôjogi, a polgári jogi, az eljárásjogi és a kereskedelmi jogi vonatkozásban megvalósított átvétel, amely a szerzô szerint egy nyugatias jogrendszer vázát honosította meg. Nyilván ezekben az esetekben, ezen szabályoknak a vizsgálata a nyugati jogon nevelkedett elmék számára egyszerú, bár kétségtelenül helyesen mutat rá a szerzô, hogy ezeknek az átvételeknek a társadalmi valóságban megjelenô drámai következményeivel számolnunk kell, még akkor is, ha a társadalomtudományok csak mostanában kezdik felismerni mindezen változások jelentôségét.

Az utólagosan hamisnak bizonyult előfeltételezés az volt, hogy a modernizáció elsöpri majd az archaikus elemeket (ilyennek tekintették nyugati oldalról a babonákat, a vallásosságot, a hagyományos szokásokat vagy a kasztrendszert). Azonban éppen az elvárttal szemben ellentétes hatások, ellenhatások következtek be. Vagyis ahelyett, hogy elfordultak volna ezen társadalmak a tradicionális gondolkodástól, éppen az ún. retradicionalizáció jelensége következett be az 1970-es évektôl kezdve, mégpedig a reiszlamizáció (Jany, 2016b:25-29) formájában (elég az iráni iszlám forradalomra, az ezt követố globális dzsihádizmusra, valamint az arab tavaszra gondolni).

Ez a hagyományokhoz való visszatérés azonban nemcsak az iszlám világra jellemzô, hanem Kínára is, ahol a konfucianizmus sokadvirágzásával találkozhatunk. A kommunista (maoista) irányítású kínai állam mindezt nyíltan támogatja: elég csak arra emlékeztetnünk, hogy maga Mao Ce-tung sem vágott el minden gyökeret a klasszikus kínai kultúrával kapcsolatosan, hiszen ó maga személyesen is gyakorolta a kalligrafikus szép- 
írást, illetve klasszikus kínai verseket írt (Mao, 1959). Sốt vannak olyan nézetek, amelyek a konfuciánus világlátást egyenesen a globális problémák panáceájaként ajánlja. Indiában is találkozhatunk az európai mintáktól elfordulást, a hindu gyökerekhez való visszatérést hirdetố politikai párttal. A kommunista örökségtôl megszabadult Kambodzsában a buddhizmust államvallássá tették. Mindezen folyamatok indokolják, hogy a szerzố a tradicionalista jogrendszereket ne hagyja figyelmen kívül.

A kötet nem a nyugati jog ázsiai recepcióját írja meg, hanem azt saját képi jogrendszerként tekinti. Fontos ezzel együtt kiemelni a szerzố azon szándékát, mely szerint a fejezetek inkább enciklopédikus összefoglalások, semmint egy-egy részterület analitikus feldolgozásai. Nyilván a szerzố sem hallgatja el, bár pontosan nem jelöli azt a múvét, amely mégiscsak egy ázsiai jogi részterületnek az enciklopédikus összefoglalása, nevezetesen a klasszikus iszlám jogé (Jany, 2006:1-520). Maga Jany János is kimondja, hogy a korábbiakban monografikusan bemutatott klasszikus iszlám jogra jóval kevesebb terjedelem jut (kevesebb mint 100 oldal), ez ugyanakkor múfaji sajátosságnak tekintendô. Hiszen valóban igaz az, hogy a terjedelmi korlátok tekintetében jelentkezó aránytalanság magát a múvet is torzítaná, de ezt a szerzố rendkívül elegánsan meg tudta oldani.

Fontos még a bevezetésbő́l az a gondolatiság is, hogy valóban nem csupán jogtörténetet ír a szerzố, hanem a specifikus ázsiai nézôponttal együtt járó - és a jog világára nem egy esetben valóban ható - kultúrtörténeti alapokat (ideértve a vallást, a szokásokat) kellố mértékben tisztázza. Ugyanakkor nem lehet elmenni amellett sem, hogy az alcímben a jogtudomány szó is szerepel, ugyanis az egyes jogtudományok különbözố nézôpontjainak feltárása nélkül könnyen abba a helyzetbe juthatnánk, hogy az egész vállalkozás a pusztán teoretizáló szociologizálás mezejére esnék. Mindemellett tisztában kell lennünk a szerzó azon megállapításának fontosságával, hogy a keleti jogrendszerekkel való foglalkozás nem új keletú diszciplína, de nyilvánvaló okokból nem is annyira klasszikus, mint a római jog múvelése. Ennek oka részben az, hogy ezeket a földrajzi területeket az európai stílusú klasszikus társadalomtudomány múvelói a 18. század elốtt nem kellóen ismerték. Ezt a megismerést nem szándékoltan, de elômozdította az amúgy mélyen elítélendô gyarmatosítás is. Világos azon felvetés, hogy e területeket hadászati szempontból uralni, adminisztratív szempontból pedig igazgatni kellett, mégpedig földrajzilag nagy kiterjedésú területeket és jelentôs számú lakosságot. Ez a szükségszerúség magával hozta a helyi hagyományok, illetôleg a helyi jogok megismerésének szükségességét. Nyilván más volt a hozzáférhetôség az írásbeliséggel rendelkezô civilizációk, valamint a szóbeliségen alapuló kultúrák tekintetében. A könnyebben megoldható feladatot jelentette ezen a területen például a viszonylag ismert, korai zsidó jogról való tudás rendszerbe foglalása, hiszen még a 20. század elején is, az akkor még alapvetôen latin nyelvú teológiai képzésben, a héber és az egyéb keleti nyelvek ismerete (Óriás, 2006:56-83) ${ }^{9}$ az Ószövetség eredeti nyelvú változatainak megismerése miatt, sokkal hangsúlyosabb volt, mint esetlegesen ma. Azaz ilyen módon, ha nem is közvetlenül a nyugati jogtudományban, de a teológiához kapcsolódó tudományos határterületeken, az ószövetségi zsidó jog ismertnek volt tekinthetô; szemben például azzal a másik szélsôértékkel, a mezopotámiai joggal, amelyet az ékírás megfejtése, illetôleg a Codex Hammurapi szerencsés elốkerülése jelentett. Ez a 
fajta jelentôs konstelláció volt az oka, hogy a 20. század elejétôl a mezopotámiai jog kutatása is megkezdôdhetett.

Az ázsiai jogok problematikájával kapcsolatban nagyon jelentékeny az az eszmetörténeti összefoglalás, amelyet a kötet bevezetésének 22-31. lapjain olvashatunk. Nyilván a jogtudósok bekapcsolása a kérdés vizsgálatába viszonylag késôn történt meg, hiszen gyarmati tisztviselôk, bírák, más gyakorlati jogász szakemberek már szükségképpen jóval korábban az egyes helyszíneken tartózkodtak. Jany János - egyébiránt megalapozottan - meglehetôsen sötét képet fest az elsô keleti jog kérdéseivel foglalkozó jogtudósokról. Ők a mindenek felett álló római jog és saját joghagyományuk tükrében szemlélték a helyi viszonyokat, egyébként meglehetôs leereszkedéssel és lekezelő módon. A szerzô ilyenként emeli ki az ind helyi jogok vonatkozásában Sir Henry Maine-t (jogantropológiai kutatásaira lásd Maine, 1997). Mindazonáltal nem lehet eltagadni ezen elsố nyugati jogtudósok eredményességét, hiszen a nagy ázsiai jogrendszerek jellegadó szövegeinek elsô fordításai (Hammurapi, valamint Manu kódexei, illetve egyes burmai jogi szövegek) hozzájuk köthetôek.

Igen szép bemutatása a jog és az orientalisztika határán fekvô tudományterületnek a bevezetô részben a 22-29. oldalak. A magunk részérôl az ilyesfajta, életmúveken keresztül történó, tudományelméleti bemutatásokat tartjuk a legértékesebbeknek, és be kell vallani, hogy ezek az államtudomány és jogtudomány területén kevésbé tekinthetôek gyakorinak (a hazai társadalomtudományok körében alapvetően szintén nem gyakoriak ezek az önreflektív tudománytörténeti tendenciák, alapvetôen ez alól csupán az irodalomtörténet tudománya jelent valamelyest kivételt). Érdemes röviden utalni a jogi orientalisztika elmélettörténeti irányzataira. Jany János elvi éllel rögzíti, hogy a könyvében is vizsgált tudományterületet alapvetôen zömmel nem jogtudósok, hanem filológusok múvelték, vagyis olyan nyelvtudósok, akik a szövegeket olvasni tudták, illetve kellô történeti, nyelvészeti, irodalomtudományi felvértezettséggel a megfelelő értelmezésre is képesek voltak.

Fontos mérföldköveknek azokat a tudománytörténeti pillanatokat tartja, amikor vagy egy-egy jogvégzett, vagy a jogtudományi kérdéseket középpontba állító orientalista fellépésére került sor, közülük az iszlám joggal foglalkozott Joseph Schacht (Schacht, 1950), az indiai és délkelet-ázsiai jogot kutató Robert Lingat (Lingat, 1973), továbbá az indiai és a zsidó jog területén ténykedô J. D. M. Derrett (Derrett, 1968). A filológia és a jogtudomány képviselôi összefogása eredményeként született meg a babiloni jog tekintetében G. Driver és J. Miles (Driver-Miles, 1952-1955) munkássága. Az elméleti jogtudomány törekvései mellett ezen a területen a gyakorlati szakembereknek is szerep jut, óket nyilván nem a jogelméleti vagy az orientalisztikai problémák izgatták, hanem a gyakorlati jog követelményei (tehát a felmerülő mindennapi jogi ügyek) megoldásának szándéka vezette, hogy a joganyagot összerendezzék vagy magánkezdeményezésre kodifikálják. Ezen törekvések azonban ellenállást keltettek a helyi lakosságban, akik nem tudták hová tenni a jelenséget, így az ilyesféle projektumokat abba kellett hagyni. Ez történt a Sparks Code esetében is.

Fontos megállapítás, hogy az orientalisztikai jogtudományt még mindig nem sikerült kellóen kibontakoztatni, annak ellenére sem, hogy a napjainkban a sok ismétel- 
getéstôl lassan kiüresedő, jelszószerú interdiszciplinaritás, valamint a csapatmunka ebben az esetben valós és hasznos eredményekre vezethet. A gyarmati uralom lazulásával és megszúnésével, illetôleg a közvetlen gyarmati igazgatás eltûnésével napjainkra a tudományos kutatások kerültek ezen a területen előtérbe. Mindez azzal járt, hogy néhány amerikai egyetemen felállítottak ázsiai jogokkal foglalkozó kutatóközpontokat, illetve Európában megjelent néhány orientalisztikai irányultságú jogtudományi társaság. Ilyen példának okáért a német kezdeményezésú European China Law Studies Association. ${ }^{10}$ Ugyanakkor mindenképp szükséges utalni a szerzô azon megállapítására, hogy a jogtudomány nyitási kényszerének ilyetén jellegú felismerése nem jelenti azt, hogy itt valódi interdiszciplináris kutatásokról lenne szó, mivel ezek a gyakorlatban alig valósulnak meg. Teljességgel egyetértünk azokkal a további állításokkal, hogy az ilyen irányú kutatások alulfinanszírozottsága és az egész témakör negligálása a valós kép, ugyanakkor valóban tény, hogy az ázsiai jogrendszerek ismeretének szükséglete aktuálisabb, mint valaha. Mindehhez képest akár Észak-Amerikában, akár Európában nagyon gyakran csak pszeudo-interdiszciplináris kutatásokkal találkozunk, amelyek inkább csak fokozzák az amúgy is meglévő zavarodottságot, és a jogtudósok esetében gyakran csak az identitásválság kialakítására alkalmasak. Akár olyan irányban, hogy részben az Amerikai Egyesült Államok jogtudományában zajló folyamatok hatására a hazai jogtudománnyal foglalkozók között is egyre több a jogot amúgy hírból sem ismerô szociológus vagy politológus; illetve a fent említett elbizonytalanodás hatására akadnak olyan jogvégzett és jogtudománnyal foglalkozó kutatók, akik sokkal inkább szociológiai és politikatudományi kérdéseket oldanak meg jogtudományi kutatások örve alatt, nem a valós jogi problémákat. Az identitásválság másik típusú áldozata azon kevés számú kutató, aki jogdogmatikai vagy a dogmatikai kutatásokat segítô tudományelméleti és elmélettörténeti kutatásokat folytat. A fenti változás ezekben a körökben is elbizonytalanodást eredményez, különös tekintettel az olyan hangok keltette félelmekre, mely szerint a dogmatikai kutatások válságban vannak, illetve hogy maga a jogdogmatika halott. Azért nem árt figyelemmel lenni arra, hogy a jogtudomány mindennapi problémáit mégiscsak a jogdogmatika eszközeivel lehet megoldani, ugyanis az itt jelentkezô kérdések megválaszolására egy sor tudomány képviselői, a szociológusok, a politológusok, a pszichológusok, a történészek, a statisztikusok, valamint a jogtudományi álarcban jelentkezó különféle ideológusok (például az ún. nyugati marxisták, a gendertudományok múvelôi, illetôleg a „jog és bármi”-vel - jog és irodalom, jog és közgazdaságtan, jog és érzelmek stb. - foglalkozók) kevéssé alkalmasak.

Az ókori Közel-Kelet kutatása tekintetében Jean Vincent Scheilt, Martha T. Rothot, V. Korošecet, G. Driverert, J. Milest, Raymund Westbrookot, illetôleg a magyar szerzók közül az orientalista Mahler Edét (Mahler, 1906) ${ }^{11}$ és Kmoskó Mihályt (Kmoskó, 1911; 1913) ${ }^{12}$ szükséges megemlíteni. A zsidó jog történeti vizsgálatában vezetô szerep illeti meg Julius Wellhausent, Martin Nothot, Gerhard von Radot, David Daubét, Calum Carmichaelt, Alan Watsont, illetooleg Peter Steint.

A keleti kereszténység szír nyelvú hagyományának jogtudományi feltárása is jelentôs - alapvetôen német ajkú - szerzôkkel büszkélkedhet: Georg Hoffmann, Eduard Sachau, Oskar Braun, Arthur Vööbus, W. Hoenerbach, O. Spies, valamint Walter Selb. 
A szerzô kissé sötét színekkel festi meg a perzsa jog kutatásának tablóját, mivel a jogi kérdések nemhogy az iranisztikai érdeklődés homlokterében, hanem még a perifériáján is alig állottak és állnak. A legjelentôsebb jogi iranisták közé sorolandók: Christian Bartholomae, Mansour Shakl, Anahit Perikhanian, illetóleg Maria Macuch.

Az iszlám jog ismerete csak a 19-20. század fordulóján kezdódött meg a nyugati orientalisztika által elvárt tudományos szinten. Nem volt annyira ismert, mint az ószövetségi zsidó jog, melynek kutatását a biblikus tudományok nagyban szorgalmazták, illetve az iszlám joggal kapcsolatosan egy sor elốitélet is terhelte a megismerést. Legkiválóbb kutatói voltak: Theodor Nöldeke, Gotthelf Bergsträsser, Snouck Hurgronje, Joseph Schacht, John Wansbrough, J. N. D. Anderson, illetve Goldziher Ignác (Goldziher, 1884). ${ }^{13}$

Jany szerint a hindu jog kutatása vonzotta a legtöbb kivételes elmét, ahol több jogi végzettségú kutatót, illetve jogász-orientalistát is találhatunk. A legjelentôsebb szerzők közé tartoztak: William Jones, Max Müller, Julius Jolly, P. V. Kane, Robert Lingat, J. Duncan, M. Derrett, Ludo Rocher, Werner Menski.

A buddhista jog kutatása az új jelenségek közé tartozik, és az elmúlt néhány évtizedben kezdôdött meg önálló diszciplínává válása, melyen belül különféle alterületekkel találkozhatunk. Az új terület számos múvelôt vonzott magához: Rebecca French (tibeti jogantropológiai kutatások), Andrew Huxley (páli buddhizmus), Emil Forchhammer (burmai és más délkelet-ázsiai jogok), Robert Lingat (burmai szokásjog), Cornelis van Vollenhoven (indonézjog), Ter Har (malájjog), M. B. Hooker (délkeletázsiai jog és maláj jog).

A kínai jog tanulmányozása majdnem közel olyan kevés szerzô fantáziáját mozgatta meg, mint a perzsa jog esetében. A kínai állam kapcsán a gyarmatosítók szerepe részben idôben rövidebb volt, mint más ázsiai országok esetében, részben nem jelentette azt, hogy a helyi igazgatással vagy jogszolgáltatással foglalkozniuk kellett volna. Ugyanakkor a konfuciánus kínai gondolkodásban, annak erôs etikai megalapozása miatt, a jog szerepe csekély volt, illetve Kínában a jogot nem tartották fontos vagy érdekes tudományterületnek, jobbára a közigazgatási kérdésekkel foglalkoztak nagyobb mértékben. Az ókorban a büntetôjog és a közigazgatási jog szerepe jelentôsebb, a magánjog szerepe csekély volt. A jog tárgyalása nem vált önálló problémává, hanem a filozófia és a történettudomány keretei között foglalkoztak vele. E körben a legkiválóbb szerzók voltak: Henri Maspero, Geoffrey MacCormack, Randall Peerenboom, Étienne Balázs (Balázs, 1931-1933; 1934; 1954; 1964; 1968; 1976) ${ }_{14}^{14}$ Laszlo Ladany (Ladany, 1992) ${ }^{15}$

A továbbiakban a kötet egyes fejezeteiben írt legfontosabb megállapításokat emeljük ki, ezenfelül az általunk legérdekesebbnek vélt tartalmak egy részét (tekintettel a terjedelmi korlátokra) is bemutatjuk.

\section{Állam és JOG AZ ÓkORI Keleten (35-66.)}

Az elsô fejezet magában foglalja Mezopotámia (sumerok és akkádok), Babilon, Aszszíria, valamint a Hettita Birodalom jogéletét. Mezopotámia területén már a Kr. e. 6. évezredbôl is elókerültek az emberi jelenlét tárgyi bizonyítékai, azonban az akkori viszonyokról igen keveset tudunk. 
Az Ubaid-kultúra (Kr. e. 5. évezred) idôszakát követôen az Uruk-kultúra (Kr. e. 4000-2900) megjelenése hozott döntô változásokat. A technikai fejlôdés szakaszai (kerék használata, növekvô fémelőállítás), illetve a népességnövekedésbôl eredôen a korai városok kifejlődése magával hozta az ékírás megjelenését is. Az államok kialakulásának okát (Herzog, 1999:13-80) a mai napig nem sikerült tisztázni, a legelfogadottabb hipotézis szerint a közösségi munkaszervezés (öntözôcsatornák, palota- és templomépítések), illetve késóbb az e munkákat irányító személyek váltak az állam vezetőivé (más elmélet szerint a városok a különbözó klánok vetélkedései miatt jöttek létre, akik épületek megalkotásával kívánták hatalmukat szimbolizálni).

A városállamok korában (Kr. e. 2900-2340) az alábbi fontosabb kultúrák alakultak ki: Ur, Eridu, Uruk, Sippar, Shuruppak, Girsu, Lagash, Umma. Jelentôs történeti esemény volt Umma és Lagash háborúja (Sulyok, 2012; 2013).

Korai jogemléknek számít a sumer korszakból UruKaGina lagashi uralkodó reformtáblája. Reformjainak célja az özvegyek és árvák védelme. Eltörölt különféle fizetési kötelezettségeket (imádkozási kenyér, halotti szertartás díja), illetve védte a szegények tulajdonát (házkert, szamár), így a korábbi szokásokkal ellentétben, a hatalmasok ellenszolgáltatás nélkül nem tudták elvenni. Fellépett az adósrabszolgaság ellen is. Nehezebben értelmezhető az a rendelkezés, amely szerint fel kell hagyni azzal a búnnel, hogy egy nônek két férje legyen. Egyesek ebben a poliandria eltörlését látták (Edzard és Korošec). Más szerzôk a ius primae noctis jogintézményét vélik benne felfedezni (Kuhrt), illetve a legújabb megközelítés özvegyi újraházasodásként értelmezi (Wilcke). Minden valószínúség szerint a sumer házasság monogám volt, sem a poligámia, sem a poliandria nem volt jellemzô, de a concubinatust vélhetốn tolerálták. A házasságon belül a férj kiemelt szerepét támasztja alá az a szabály, mely szerint a feleselő feleség száját forró téglával kell betömni.

Dél-Mezopotámia egységét nem a sumerek, hanem az akkádok valósították meg, és így jött létre az Akkád Birodalom I. Sharrukin (Kr. e. 2340-2284) vezetésével. Az Akkád Birodalom korából törvények, királyi rendeletek nem maradtak ránk. Alapvetôen magánjogi szerzôdéseket rögzítô sumer nyelvú dokumentumok maradtak fenn (jellemzően ingatlan-adásvétellel és kölcsönnel kapcsolatos szerződésekrôl van szó, ezek vonatkozásában a korábbi korszakban élt sumer írnokok szellemi teljesítményét átvevő szerzôdési klauzulák jelentek meg). Mivel a jogi hatás a formulák pontos betartásához kötôdött. Véleményünk szerint ez a felfogás közel áll a római jogi formakényszeres jogi eljárásokhoz (Földi-Hamza, 1996:166-181), illetve a késóbbi középkori jogi formulákhoz, például az istenítélet egyes eseteiben.

Az akkádokhoz kötôdik a ma ismert legrégebbi törvénykönyv. Erre a gyújteményre - mint Jany János elvi éllel rámutat - tévesen szokás Ur-Nammu törvénykönyveként hivatkozni. Ugyanis megalkotója Ur-Nammu utóda, Shulgi volt, aki ötvenéves uralma alatt elérte az állam megerôsítését. A törvény csupán fragmentumokban maradt ránk, szövegét Samuel Noah Kramer rekonstruálta 1954-ben. A törvény fôként büntetôjogi rendelkezéseket tartalmaz: idesorolandó példának okáért az emberölés, testi sértés és nemi erkölcs elleni deliktumok. Az emberölés elkövetője halálbüntetést érdemelt, mindemellett a talióelv teljesen hiányzott. Alapvetôen vagyoni jellegú, azaz anyagi 
kompenzációval járó büntetések tették ki a törvénykönyv szankciórendszerének zömét (az ilyen típusú büntetéseket a magyar jogtörténészek tarifális compositiónak hívják). A halálbüntetés a törvényben ritkán fordul elô, a talióelv pedig a majd csak két évszázaddal késóbb keletkezett Hammurapi-Codexben (röv. CH) jelentkezett.

A babiloni idôszakban jelentek meg különféle jogi szakkifejezések, például a jogszerúség (kittu) és az aequitas (mesharu). Az igazságosságot egyfajta kozmikus rendként képzelték el. Lipit Ishtar törvénykönyve Kr. e. 1934 és 1924 között keletkezett sumer nyelven, és zömmel a magánjogot szabályozta. A Kr. e. 19-18. században keletkezett a Codex Eshnunna, amely az elsố akkád nyelven íródott törvénykönyvnek tekintendô. Ez volt az egyetlen mezopotámiai törvény, amely alaki jogi szabályokat tartalmazott, így e kódex minôsül a világ elsô eljárási törvénykönyvének, amely a büntetôbíróság hatáskörét is tartalmazta. Mindezek mellett az ár- és bértarifákat is rögzítette, ezek megszegésére ugyanakkor nem állapít meg szankciót (ezzel feltehetőleg a lex imperfecta egyik elsố példája).

A mezopotámiai jogtörténet leghíresebb alkotása a Hammurapi-Codex, melyet egy 2,25 méter magas, fekete diorittömbbe véstek az írnokok. A jogemléket 1901-1903ben francia régészek tárták fel Szúzában, majd innen Párizsba szállították, ahol ma is a Louvre ad neki otthont. A szöveget Scheil fordította le elôször, valamint szakaszokra is osztotta azt, mivel az ókori keleti törvények nem tartalmaznak ilyesfajta szakaszolást.

Az asszír korszak (Kr. e. 2000-610) városállamai sajátos közjogi berendezkedést mutattak. Az állam élén álló személyt nem uralkodónak, hanem Isten helyettesének nevezték. Létezett városi tanács is. Ismert volt a válási pénz jelensége, illetôleg az adósságlevélból kifejlôdô - s a bemutatóra szóló értékpapírral rokon - jogintézmény. Érdekesség, hogy a férj távollétében a nôk sok tekintetben egyenrangúak voltak a férfiakkal.

Az ókor történetének legjelentôsebb ütközete volt a Muwattalish (Kr. e. 12951282) és II. Ramszesz seregei között lejátszódott qadeshi csata, ami az asszírok gyózelmét hozta. II. Ramszesz és Muwattalish utóda, III. Hattushilish (Kr. e. 1275-1245) kötötte meg Kr. e. 1269-ben az egyiptomi-hettita békeszerzôdést, amely az egyetemes diplomáciatörténet egyik kiemelkedô dokumentuma, ennek másolata a New York-i ENSZ-székház falát díszíti (Sulyok, 2014).

$$
\text { A zSIDó JOG }(67-104 \cdot)
$$

A zsidó joggal kapcsolatos egyik háttérprobléma a Biblia szövegével kapcsolatos hitelességi kérdések. A modern történészek többsége a biblikus állításokat nem kezeli kész történeti tényként, sốt egy kisebb csoport a történetírás során teljesen figyelmen kívül hagyja. A közvetítố irányzat a Biblia elbeszéléseit alapul veszi, de forráskritikával kezeli azokat. Saul és Dávid királyságában a bírósági szervezet nem épült ki, a bírák személyesen vettek részt az ítélkezésben. Döntésük alapját a mindenki által ismert és elfogadott szokások jelentették. A királyság korában az igazságszolgáltatás feje az uralkodó volt (Salamon korából erre emlékeztet a „salamoni döntés”), ezzel együtt a bírósági szervezet a laikus elem megjelenésével differenciáltabbá vált. Problematikus a bírósági 
szervezeti jog körében a Sanhedrin (vagy görögösen: Synhedrion) megítélése, ugyanis e névvel vagy két azonos nevú, de különböző funkciójú szervet, vagy pedig egyetlen, igen széles hatáskörú intézményt jelöltek. A rabbinikus források jogszolgáltató, illetve esetenként legiszlatív funkciókat ellátó szervként írják le, míg a görög szövegek a király vagy fớpap által vezetett, politikai döntéshozó szervként ábrázolják. A többségi álláspont szerint volt egy jogszolgáltató és egy politikai intézmény egy név alatt. Ugyanakkor jelentôs számú tudós szerint az ellentmondásos források nem támasztják alá, hogy két szervet tételezzünk fel. Ezen álláspont hívei szerint a Sanhedrin különbözô korokban eltérô funkciókat látott el, a vezetôi is mások voltak, illetve a rabbinikus források és a görög szövegek azért adnak egymástól különbözô leírást, mert más történeti korokban keletkeztek.

A Talmud elôtti korból két szóbeli szokásjoggyújteményt lehet említeni, a Misnah-t és a Toseftát. A Misnah fơleg dologi, családi, kártérítési anyagi és eljárásjogi normákkal és vallásjogi szabályokkal foglalkozott. A rabbinikus joghagyomány másik forrása a késóbb megjelenố Tosefta, mely részben kiegészíti, részben kommentálja a Misnah szabályait. A jeruzsálemi és a babiloni Talmud a Misnah tanulása során felvetôdô kérdések és válaszok tárháza.

A Talmud utáni korszakban következett be a Talmud végsố redakciója, majd késôbb a mezôgazdaságból élố közösség helyett a kereskedelembôl és iparból élố társadalom igényeihez igazítása (beleértve azt is, hogy egyre több iszlám jogi elem épült be a zsidó jogba a szerzôdéses kapcsolatok révén). A Kr. u. 9. századra a responsum irodalom mint önálló jogtudományi múfaj megerôsödött. Igen fontos volt Moses Maimonides (1135/1138-1204) responsumainak hatása, aki a keleti és a nyugati zsidóság jogi kérdéseiben rejló ellentéteket igyekezett összefésülni.

Az újkor hajnalán, 1565-ben jelent meg Velencében Joseph Qaro Sulhan Aruk címú múve, amely laikusok által is érthetôen foglalta össze a zsidó jogot, így vitathatatlan népszerúségre tett szert. Napjainkig ez a legnépszerúbb joggyújtemény. Érdekes jelenség, hogy a 17. századtól kezdve a korábbi jogtudósokat nagyobb tudással rendelkezônek tartották, mint a kortárs és a következó generáció tagjait. Az újabb generációk megvitathatták ugyan az elődök munkáit, de feltételezett hiányzó autoritásuk miatt nem változtathatták meg az elôdök által kimondottakat. Hasonló vélemény alakult ki a Talmud utáni korszakból is, és ez a tendencia az iszlám jogban is megfigyelhetố volt, ahol a 9. századig múködô jogtudósokat nevezték megkérdőjelezhetetlen tudású régieknek, míg az újak nem vetélkedhettek velük. Meg kívánjuk jegyezni, hogy nyilván másabb, de hasonló gyökerú problémára utal a római jogban az öt római remek jogász és az ó autoritásuk sorrendjét megállapító 426-os lex citationis (Földi-Hamza, 1996:94). A zsidó jog fôbb intézményei a családi jog és az öröklési jog, a büntetôjog, illetve az eljárásjog szintjén vizsgálható (91-103.).

A modern zsidó jogot Palesztinában a britek elismerték, a common law és az equity szabályait csupán kisegítô jelleggel alkalmazták. A kisszámú újítás a jogtudósok által megkezdett folyamatokat folytatták, különös tekintettel a nôk jogainak kiterjesztésére. Ez a trend a modern Izrael államának létrehozatala után is folytatódott, azzal együtt, hogy a zsidó vallásjog számos tudományos politikai és jogalkalmazási vita forrása. 


\section{A PERZSA JOG (105-147.)}

Az átlagos, kontinentális jogon nevelkedett elme számára az egyik talán legnehezebben befogadható fejezet a perzsa jogra vonatkozik. A szerzó életmúvébôl következóen, számára viszont ez az egyik olyan terület, amelyen a legotthonosabban mozog. A Perzsa Birodalom vonatkozásában nagyon fontos a belsố struktúra kiépítése, amely I. Dareiosz nevéhez fúződik, aki az államot adminisztratív és adóügyi szempontból tartományokra (szatrapia) osztotta. A tartományok élén a szatrapa (khshachapavan)állt. E tisztség története vélhetốn a méd korszakig nyúlik vissza. Dareiosz a szatrapákat a centralizált közigazgatás érdekei szerint eljáró hivatalnokokká formálta. A szatrapa a civil közigazgatást irányította, a hadügyi igazgatást a katonai parancsnokok látták el. A szatrapa a belbiztonság és az adószedés, valamint az államszervezés irányítása mellett a tartományban legfelsôbb bírói fórumnak is minôsült. Dareiosz arra is ügyelt, hogy a szatrapák ne tehessenek szert túlzott hatalomra. A helyi igazgatás mellett folyamatosan kiépítették a központi igazgatást is, ennek székvárosa Szúza volt.

Felmerült, hogy I. Dareiosz kibocsátott volna egy egységes birodalmi törvénykönyvet, amelynek alapja Hammurapi törvénye lett volna. Mindez abból ered, hogy néhány szerzố hitelt adott egyes ókori források kétértelmú utalásainak. Nyilván léteztek az egész birodalomra kiterjedô perzsa királyi adminisztratív rendeletek, ám ettôl még nem lehet egységes birodalmi jogról beszélni; amit biztosra vehetünk, hogy Dareiosz állítólagos törvényéből egyetlen betú sem maradt ránk.

Peres ügyek vonatkozásában tudjuk, hogy a király személyesen nevezte ki az eljáró bírót. A perzsa királyok igen ügyeltek a bírói pártatlanságra és a jogszerú eljárásra is. A történet szerint egy alkalommal egy Sisamnés nevú bírót megvesztegettek, aki hamis ítéletet hozott. Miután ez kiderült, Kambysés megölette a bírót, majd lenyúzott bôrébôl készíttette el a bírói pulpitust, melyre a kivégzett bíró fiát ültette, emlékeztetve hivatalának fontosságára. E történet Hérodotosztól való, aki szerint egy másik királyi bírót Dareiosz feszíttetett keresztre korrupció miatt. A Kr. u. 4. században élt történetíró, Ammianus Marcellinus azonban cáfolta, hogy a perzsák megnyúznák a hamisan ítélố bírót, és kitalációnak vagy régmúlt idók letûnt szokásának minôsíti mindezt. Emlékeztetni kívánunk arra a tényre hazai jogunkból, hogy Werbốczy Hármaskönyve (1517) szerint a hamisan ítéló bírót le kell fejezni. ${ }^{16}$

A perzsa jog történetének második fontos korszaka a Szászánidák korszakára esik, amikor a jog differenciálódott, mindazonáltal vallási alapúvá vált. Törvényeket és királyi rendeleteket ebből a korból sem ismerünk, így a korai Szászánida-kor jogélete szinte teljes egészében homályban marad elôttünk. Azonban az utolsó száz év története jobban dokumentált. A Kr. u. 7. század elsố felében íródott az ún. Ezer itélet gyújteménye (Madigan i Hazar Dadestan, röv.: MHD+A).

A zoroasztriánus perzsa jog történetének harmadik nagyobb korszaka a Szászánidák bukását követô, napjainkig tartó idôszak. Az iszlám elóretörése miatt a zoroasztriánus jog egy kisebbségbe szorult vallási közösség normarendje, ahol a joghagyomány korábbi kifinomultsága a zoroasztriánus jog elméletét és forrásait erôsen meghatározta, és részben talán korlátozta is a vallásjogi jelleg. Xerxész egyik feliratában a hívốket 
arra buzdította, hogy tiszteld azt a törvényt, amelyet Auramazda rendelt el (data paridiy tya auramazda niyashtaya). Ez a törvény azonban nem ölt konkrét formát, mivel ilyen joganyag írott törvény formájában nem létezik. A jog jelentésú data kifejezés kettôs értelemmel bír: jelenti egyrészrôl az isteni jogot (ius divinum), továbbá jelenti az uralkodó által meghatározott törvényt is.

A zoroasztriánus jog legfôbb forrása egy Awesta nevú vallási szövegkorpusz, amely a Szászánida-korban keletkezett. A megváltozott életviszonyokhoz azonban ezeket az elốrásokat már nem lehetett alkalmazni, ezért közvetlenül csupán két ma ismert bírói ítélet hivatkozik az Awesta normáira, holott a vallási normaszöveg elméleti jelentôsége a jog szempontjából is vitathatatlan, még akkor is, ha ez a jelentôség és a gyakorlati alkalmazhatóság fordítottan is aránylik egymáshoz. A joggyakorlatban a jog forrásává a szokásokon alapuló jogtudósi doktrínák váltak (chashtag). A jog és bírói ítéletek harmadik forrása a jogtudósok konszenzusa volt (hamdadestan $i$ wehan). Ez sokban emlékeztet az iszlám jogban az iijmára, azonban nem derül ki, hogy ez a kifejezés valamennyi jogtudós konszenzusát vagy egy jogtudósi iskola konszenzusát takarja-e, és jogforrási ereje iszlám társánál gyengébb. Ugyanakkor több ítélet is nyugodott konszenzuson a perzsa jogban is. A bírói ítéletek negyedik forrása a bírói szokásjog (kardag). A perzsa jogi fejezet alapján úgy túnik, hogy a bírói ítéletek forrásai közül a bírói szokásjog volt a „legélóbb”. Az ügyek ismertetése során szokás volt a versengó doktrínák leírása, és ezt követte a bírói szokásjog általi megoldás megadása.

A szerzô a zoroasztriánus jog fơbb intézményeiként ismerteti (126-143.): a házassági jogot, a büntetôjogot, az eljárásjogot (ezen belül a büntetô eljárásjogot és a polgári eljárásjogot egyaránt). A zoroasztriánus jog egyes múfajai még a 18. században is szokásban voltak (igaz, újperzsa nyelven), azonban az újkorra a joghagyomány jelentôs része ezzel együtt is feledésbe merült. A muszlimok zaklatásai elôl a zoroasztriánusok (párszik) számára az identitás megórzését a vallásgyakorlás jelentette, így a jog szerepe csökkent. A párszik nem fértek hozzá saját korábbi szövegeikhez, ezek részben nem voltak már meg, részben a korábbi nyelvállapotot nem tudták megérteni. A párszik elzárkózása, az alacsony gyermekszám, a kései házasságok, valamint a házasságban nem élôk igen magas aránya a párszi közösséget a teljes eljelentéktelenedés irányába viszik, amely magában foglalja a teljes eltûnés veszélyét is.

\section{A KELETI KERESZTÉNYSÉG JOGA ( $148-188$.}

A kereszténység keleti terjeszkedésének kezdetei nem ismertek számunkra. A történeti tényeket utólagosan nem lehet már megállapítani. Feltételezhetően a kereszténység keleti terjeszkedésében a Szíriában élố zsidó közösségek játszották a legfontosabb szerepet, akárcsak a nyugati elterjedés esetében. A Palesztinából keletre induló missziók Szíria irányába terjeszkedtek. Itt szükséges megemlíteni a szír nyelvú mártírakták 1880-es elsố kiadását (Georg Hoffmann). ${ }^{17}$ A keleti kereszténység kifejezés legtágabb értelemben valamennyi, a latin kereszténységen (a latin rítusú római katolikus egyházon) kívül esik, ideértve a bizánci, az orosz, a kopt és az örmény egyházakat is. 
Azonban a szerzố ebben a fejezetben csupán annak az egy egyháznak a jogéletét dolgozza fel, amely a Kelet Egyházának nevezte magát, azaz a keleti szír egyházat, amely Perzsiáig terjedt, de missziós tevékenysége egészen Kínáig ért (azért is hívták keleti szír egyháznak, hogy meg lehessen különböztetni a nyugati szír vagy jakobita egyháztól). Szükséges megjegyezni, hogy a késô ókori Közel-Kelet keresztény egyházát némileg megtévesztôen nesztoriánus egyháznak is nevezik.

A keleti kereszténység esetében különálló jogtudomány nem létezett, így olyan jogtudósok sem voltak, akik ne értettek volna más tudományokhoz, azaz a jogtudományt polihisztorok múvelték. Igen fontos a szerzó azon jellegadó megállapítása, hogy a Kelet Egyházának joga teljes fennállása alatt ellenséges környezetben épült ki. A püspököknek világi ügyekben is volt joghatóságuk. A vagyoni vitákat római jogot is tartalmazó jogkönyv alapján rendezte a keleti jog (szír-római jogkönyv vagy Sententiae Syriacae). Azonban ez a jogkönyv csak akkor volt alkalmazható, ha mindkét fél keresztény volt; amennyiben e tény nem állott fenn, akkor a perzsa/iszlám jogot alkalmazó állami bírósághoz kellett fordulni. Fontos kiemelni, hogy jelentôs forrása volt a keleti egyház jogának a késố római jog, illetve az annak keleti recepcióját tartalmazó szövegek.

A joganyag nagy részét a házassági jog tette ki, az öröklési jogra pedig ennek folytatásaként tekintettek. Érdekes megállapítás, hogy a vagyonjog szerepeltetése nem valamennyi jogkönyvben fordult elô, hanem csak azokban, amelyek a teljességre törekedtek. A vagyonjog materiális alapvetése és anyagias emberképe kevéssé fért össze a magasabb eszméket hirdetô egyházias gondolkodással.

Sajnálatos, de az adott történelmi körülmények között nyilvánvaló, hogy a különféle gyújteményekben közigazgatási szabályok nem voltak, ugyanis a keleti kereszténység joga nem egy adott államnak volt a jogrendszere, így valójában egyházi közigazgatási joggal találkozunk, amely az egyházszervezeti szabályokat rendezte, illetôleg részletekbe menôen szabályozta a hierarchiát, a püspök és a metropolita jogkörét, a területi hatály és az egyéb szervezeti kérdések problematikáját is ideértve.

Ugyanígy teljesen hiányzik a jogkönyvekből a büntetôjog, mivel a keleti keresztényeknek nem volt saját államuk, így a mindenkori állam élt ezzel a joggal. Egyes házasság elleni bûncselekményekre kiközösítést, illetve vezeklést ismertek. Egyetlen jogkönyvben fordul elő az emberölési tényállás, amelynek szankciója a kiközösítés volt.

Ebben a jogrendszerben az eljárásjog sem fejlôdött ki, az effajta jogtest kidolgozatlan maradt. Azonban valamifajta kezdetleges bíróság elootti és házassággal kapcsolatos eljárás létezett.

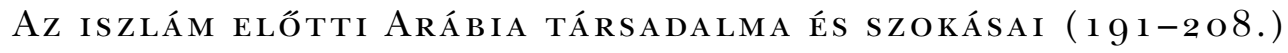

Az iszlám jogi kultúrkörbe tartozik az iszlám elôtti Arábia társadalma és szokásai, amelyekbôl a szintén e körbe tartozó klasszikus iszlám jogban rendkívül sok minden visszaköszön. Az arabok már a Kr. e. 1. évezred során kapcsolatba kerültek az ókori Mezopotámia történetével. A szerzô e kapcsolatok részletei felôl részletekbe menôen 
eligazítja az olvasót. Fontos tudni, hogy a Kr. u. 300 körüli évektôl az arabok luxuscikkekkel (tömjén és mirha) kereskedtek. Ezenkívül jelentôs volt a déli arab-tengeri kereskedelem is. A külsố megfigyelôk a luxuscikkek behozatala miatt Arábiát távoli és gazdag vidékként tartották számon, innen ered a terület romanticizáló latin elnevezése (Arabia felix).

A korábban felépített Limes Orientalis, mely Észak-Mezopotámiától a Vörös-tengerig húzódott, kettévágta a területen élő arab népességet. A limesen belül élőket rhomaioinak, az azon kívül lakókat szaracénoknak hívták. A bizánciak egyes arab törzseket szerződéses jogviszony keretében határôrizettel is megbíztak, a foederati rétegbe emelve e népelemeket.

A kötet fontos megállapítása, hogy az iszlám elootti Arábiában egységes állami és társadalmi struktúráról nem lehet beszélni. E terület alapvetôen szokásjoggal élt. A fennmaradt kevés számú emlékből felismerhetô, hogy nem individualista, hanem tömegtársadalom volt Arabia felix. Ezt onnan tudjuk, hogy a mi személyfogalmunkhoz hasonlót nem is ismertek, hanem az egyén a közösség tagjaként bírt csupán jelentôséggel. Az egyént különféle testi körülírásokkal jellemezték, ezek közül egyesek a mi gondolkodásunkban is használatosak, például: lélek (nafs), arc (wajh), egyéb kifejezések használata a mi gondolkodásunkban ritkább, inkább a korabeli arab kultúrához áll közelebb: szellem (rüh), illetôleg szív (qalb).

A korabeli töredékes jogéletbôl csupán néhány jellemzôt áll módunkban felidézni. Ilyen volt a matrilineáris leszármazás, az emberölés szabályozása (két, városfalba vésett szövegemlék alapján ismerjük). Hozzá kell tenni, hogy a korabeli arab jogéletben a szóbeli szokásjog volt a domináns, így jogalkotásra alig került sor. A kötelmi jog köréból az adásvételre nézve van királyi decretum. Ismert volt a zálog intézménye is (ez nemcsak dolgokra, hanem személyekre is alkalmazható volt, például szolga, feleség). A ránk maradt szabályozásból nem állapítható meg, hogy a földre vonatkozó ügyletek földtulajdonjogra vagy csak a birtoklásra vonatkoztak-e. Az évszázadok előrehaladtával erôsödtek a római jogi hatások (a görögból fordított szír-római jogkönyv; Hamza, 2002:253-256).

\section{A KLASSZIKUS ISZLÁM JOG (2o9-293.)}

A mohamedán vallásnak köszönhetôen a provinciális Arábia hirtelen nemzetközi tényezôvé vált. Mohamed volt az utolsó a próféták sorában, ezért átmeneti idôre helyettest (khalifa) választottak a közösség élére. Az elsô kalifa, Abu Bakr meghódította Jement és Szíriát. Utóda, Umar legyốzte a Szászánida Iránt, elfoglalta Irakot, Egyiptomot, Jeruzsálemet, valamint Damaszkuszt. A 10. század után az oszmán-törökök váltak dominánssá, és Perzsia kivételével az iszlám világ legnagyobb részét elfoglalták, meghatározva ezzel a terület sorsát. A török szultán önmagát kalifának kiáltotta ki, ezért a kalifátus az Oszmán Birodalom megszúnéséig formálisan fennmaradt, végül Kemal Atatürk szüntette meg hivatalosan. A klasszikus iszlám jog szempontjából azonban nem ezek az idôszakok, hanem a kialakulás periódusa és a klasszikus kor viszonyai a meghatározóak. 
A 8. század elején létrejöttek az elsố iskolák (ancient schools of law). Ezek saját tanítással rendelkeztek, és egymással vitában álltak. Érdemes utalni a hanbalita iskolára, amely a bagdadi tradicionalisták köréból nôtt ki, akik tagadták a ráció szerepét az iszlám jogforrási rendszerében. A klasszikus korban a különféle jogi iskolák egyre kevésbé hasonlítottak az elôzố korszak szellemi múhelyeihez, elvesztették személyes jellegüket, és egyre inkább doktrinális jellegúvé váltak.

E helyütt nincsen mód arra, hogy az iszlám jog forrásait részletekbe menôen ismertessük, csak egy-egy jellegadó princípiumot tudunk felvillantani, de az érdeklôdố olvasó bátran fellapozhatja ismeretei bôvítése érdekében a kiváló magnum opust. Egy Allah kinyilatkoztatását alapul vevố jogrendszerben a Koránt illeti meg a jogforrási hierarchiában az elsố hely. Ez elsô látásra talán furcsa lehet a kontinentális vagy akár az angolszász jogrendszerben nevelkedettek számára, de elég csupán arra az analógiára utalni, hogy a latin rítusú római katolikus egyház kánonjogában is forrás a Biblia. ${ }^{18}$ A Korán nem törvénykönyv, bár tartalmaz jogilag releváns verseket is. A joghézag pótlása a sunna révén valósul meg. Ha a kinyilatkoztatás két fenti formája nem ad adekvát eligazítást, a konszenzuson (ijma) nyugvó norma is jogforrásnak számít. Ha sem a Korán, sem a sunna nem tartalmaz irányadó normát, az iszlám jog tudósai (mutjahid) analógia útján meghatározhattak bizonyos szabályokat.

Az iszlám jog fóbb szabályai az összes eddig vizsgált kultúrkör közül a legcizelláltabbak, éppen ezért csupán csak arra utalunk, hogy a szabályozás a jog mely területeire terjed ki. Nagyon fontos, hogy az iszlám jog (a római joghoz hasonlatosan, Földi-Hamza, 1996:52) ${ }^{19}$ nem ismeri a jogág fogalmát. Emiatt iszlám büntetôjogról mint elkülönült jogágról sem lehet beszélni, hanem csupán a bûncselekményekrôl és azok büntetéséról lehet szólni. Ez a quasi büntetôjog nem játszik komoly szerepet a klasszikus iszlám jogban, mivel csupán néhány tényállásra és szankcióra terjed ki. Az isteni jog által bûncselekménynek minôsített tetteket öleli fel a sharia jog. Minden egyéb bưncselekmény a jog által nem szabályozottnak minôsül (tazir), és az eljáró hatóság diszkrecionális jogkörébe tartozó eljárás keretei között ítélendô meg. A Korán által külön meghatározott búncselekmények a következôk: paráznaság, paráznaságra vonatkozó hamis vád, borivás, lopás, útonállás, hitehagyás. (A hitehagyás büntetése halál.) ${ }^{20}$ Egyes feltételek fennállása esetében büntetik még a szándékos emberölést, illetve egyes testi sértések okozását is.

Az eljárási szabályok meglehetôsen formálisak, és kontinentális jogi szemmel nézve részben talán funkciótlanok is. Az eljárás azért alkalmatlan és életidegen, mert az eljárás lefolytatásával nem lehet a megfelelő joghatást kiváltani. Ugyanakkor nem különítik el szigorúan a polgári és büntetőügyeket, valamint az azokhoz tartozó eljárási szabályokat sem. Mind a polgári ügyek, mind a büntetőügyek akkuzatórius (vádelvú) eljárás keretében indulnak. Az inkvizitórius (nyomozóelvú) eljárások keretébe csak a büntetôügyek egy csekély hányada tartozik. A háború és a béke joga (Grotius, 1999; Concha, 1895, I. 89-92) a magánjogra fókuszáló klasszikus iszlám jogban ugyanúgy kevéssé jelentôs, ahogy a büntetőjog is.

A magánjog hangsúlyosabb területei közé tartozik a családi jog házassági jogi része, illetve az öröklési jog. A dologi és a kötelmi jog fogalma a kontinentális, illetve az an- 
golszász jogban kidolgozott dogmatikai mélységben az iszlám jogban nem ismeretes, mert ezeket a kérdéseket a kazuisztikus, egyes szerzódésekre vonatkozó (kontinentális jogi terminológia szerint kötelmi különös részi) szabályozás során teszik meg. Legjelentôsebb ebben a körben az adásvétel szabályozása, de a bérlet, a kölcsön, a letét, illetve a társas vállalkozások (társaság jogi formák) különbözố nemeivel való foglalatoskodás is. Ugyanakkor úgy túnik számunkra, hogy az iszlám vagyonjog legjellemzôbb intézménye a waqf. ${ }^{21}$ A waqf kifejezést jellemzóen alapítványnak szokás fordítani, de Jany János helyesen mutat rá arra a tényre, hogy az iszlám jog elutasítja a jogi személy gondolatát. A jogintézmény tartalmában az angolszász trusthoz (célvagyon) áll legközelebb. Ismeretesek jótékony, közösségi célra létrejött waqfok (iskola, kórház, út, híd vagy vízvezeték létesítésére alapított intézmények), de olyan vagyontömegként is létezik, melynek célja a családtagok (azaz az alapító gyermekei és más leszármazói) anyagi biztonságáról való gondoskodás. Mindkét formában közös, hogy a waqf célja valamely vallási ideával való azonosulás vagy vallási gondolat előmozdítására irányuló szándék, ugyanis a waqf alapítása kegyes célra irányul, így a római jogból is ismert pia causa valamifajta párhuzama (Földi-Hamza, 1996:230-231).

A kötet fontos megállapítása, hogy a szunnita joggal szembeállítva, a síita jog önállósága meglehetôsen relatív. Mivel a síita jog a szunnita joghoz hasonlatosan erôsen magánjogi dominanciájú, a különbségek csupán a házassági jog és az öröklési jog területén, három kisebb kérdésben jelentkeznek.

A modern kori iszlám jog lehetséges értelmezési kérdései igen sokfélék. Ennek körében arra kívánunk utalni, hogy létezik egy, a jog modernizációját nyugati mintára elképzelố (westernizációs iskola), illetôleg e mellett él a tradicionális jogfelfogás is. Az iszlamizmus jogfelfogásán belül rendkívül érdekes az iráni iszlám forradalom jogtana, amely alapvetốn Homeini ajatollah személyéhez kötôdött. Homeini az államformát illetốn a köztársaságot részesítette elônyben. Az alkotmány központi eleme a jogtudós uralmának elve (welayat-e faqih) volt. Ennek az elvnek még a vallásjogászok között is gyenge volt a magyarázó ereje, mivel alapvetôen a jogtudós uralma a többségi vélemény szerint erkölcsi, vallási és jogi útmutatást jelentett, nem pedig a mindennapi politikai döntéshozatalra szolgáló alkotmányos pozíciót. Ettôl függetlenül a jogtudós uralmának elve vált az új iráni iszlám alkotmány vezérfonalává. Ennek lényege az, hogy a legkiválóbb jogtudós (esetünkben Homeini) jogosult a közösség vezetésére, és ez a tény a napi politikai életben való részvételre, valamint az állam vezetésére is feljogosít, egyedüli és megkérdójelezhetetlen autoritásként. Mivel ezen alapelv politikai ideológia, alkotmányos alapelv, közjogi alapvetés és teológiai dogma is volt egyben, így kétségbevonása nemcsak a rendszer politikai alapvetésének tagadását, hanem a teológiai fundamentum megkérdőjelezését is magában foglalta. Hogy mennyire a mindennapok jogát jelentette ez az elv, arra példa a Hasham Aqajeri-ügy, aki tagadta a legkiválóbb jogtudós uralmának elvét, illetôleg megkérdójelezte a jogtudósi autoritást, ezért 2002-ben a bíróság blaszfémia vádjával halálra ítélte (ha jól értjük a megfogalmazást, mivel a blaszfémia istenkáromlást jelent, valójában ebben a tényállásban a teológiai dogma tagadása túnik a legsúlyosabb tényállási elemnek, amely a legsúlyosabb büntetési nem alkalmazását lehetôvé teszi). 


\section{Polgári Szemle · 13. évfolyam 4-6. szám}

\section{JEGYZETEK}

1 A tanulmány az MTA Társadalomtudományi Kutatóközpont Jogtudományi Intézete Közigazgatási Jogi Kutatócsoportjának Az állami szerepkörök változásának hatása a közigazgatás helyére és szerepére az állami szervek és funkciók rendszerében elnevezésú kutatási fôiránya keretében készült.

2 Ennek a sajátos múfajnak talán legszorgalmasabb honi múvelóje, a közigazgatástan hazai atyamestere Concha Gyôzố (1846-1933), az MTA másodelnöke volt. Lásd Concha, 1871; 1876; 1891; 1892; 1908.

3 A legutóbbi idốkbôl lásd Koi, 2016.

4 Lásd Coing, 1985; 1989; Grossi, 2010; Wesel, 2010.

5 A témára lásd a két alábbi kitúnô és nagy ívú jogelméleti összefoglalást: Tamás, 1977; 1980.

${ }^{6}$ Az idézettekre vö. Carr-Mahalingam, 2000. A szerzô által felidézett jelentős összefoglalás az ázsiai filozófusok közül csupán néhány kiemelkedô életmúvet hangsúlyoz (Konfuciusz, Avicenna, Al-Farabi), egyebekben a jelentôs bölcselettel bíró perzsa, arab, kínai, japán, illetôleg tibeti filozófiai iskolák (zoroasztriánus, buddhista, iszlám, konfuciánus), gondolkodásmódok egyes korszakait, illetve különféle problémáit (nyelv, filozófia, marxizáló és maoista tendenciák, logika és erkölcstan szerepe) dolgozza fel. Érdekes ezzel a tendenciával összevetni egy másik általunk ismert, egyebekben az utóbbi vállalkozást idôben is megelốzô múvel (McGreal, 1995). E kötet, az elôbbi enciklopédiával ellentétben, többségében az egyes bölcselốk életmúvének és nézeteinek az eszmetörténeti kézikönyve. Adott esetben egyes múvekkel is foglalkozik (India esetében az Upanisadokkal, Kína esetében olyan nagy jelentôségú múvekkel, mint a Da Xue, a Zhong Yong és a Yi Jing). Ha csak az egyes gondolkodókat vesszük tekintetbe a vizsgálódás horizontjának kezdetétôl annak végéig, akkor ennek tekintetében szemlélhetjük a kínai filozófiát Konfuciusztól (Kr. e. 551-479) egészen Fung Yu-lanig (1895-1990); India esetében Buddhától (Kr. e. 563-483) egészen Jawaharlal Nehruig (1889-1964); Japán esetében Shotoku Taishitól (574-622) egészen Nishitani Keijiig (1900-1990); Korea esetében Wonhyótól (617-686) egészen Han Yongunig (1879-1944); az iszlám világ esetében Rabi’a al-Adawiyyától (714-801) egészen Sayyid Muhammad Husain Tabataba'i-ig (1903-1981).

7 A Hamza-mú a középkori fejlődés körében olyan korábban kevésbé figyelembe vett országok jogfejlôdését is feldolgozza, mint Litvánia, Wales, Izland, Bulgária, illetôleg Havasalföld és Moldva. Az újkori vonatkozások tekintetében olyan kisebb jogi kultúrákat is tekintetbe vesz, mint Liechtenstein, Luxemburg, Monaco, San Marino, Málta, Andorra, a Csatorna-szigetek, Man-sziget, Izland, Macedónia, Albánia, Besszarábia, Grúzia, Örményország, Azerbajdzsán. Az észak-amerikai fejlôdés vizsgálata során olyan sajátos területek helyzetét is elemzi, mint Louisiana, valamint Puerto Rico (az USA társult állama). Sok tekintetben hiánypótló Közép- és Dél-Amerika fejlôdésének feldolgozása, benne olyan szerényebb jogi kultúrákkal, mint Haiti, Honduras, Nicaragua, Panama, Salvador, továbbá Ecuador, Guyana, Paraguay, Suriname, Uruguay. Ezenfelül a dél-afrikai jogfejlódés érzékletes képét is megfesti. Dél-afrikai jogfejlôdésen jelen esetben nemcsak a mai Dél-afrikai Köztársaságot és a Dél-afrikai Uniót kell érteni, hanem mindazokat az egyéb országokat, amelyek az ún. római-holland joggal (afrikaans nyelven Romeins-Hollandse reg, angolul Roman-Dutch Law) élnek. Ezek közé tartozik Botswana (korábbi nevén Becsuánaföld), Lesotho (korábbi nevén Bászutóföld), Namíbia, Szváziföld, illetốleg Zimbabwe. Ázsiát illetôen olyan kisebb területek magánjogi életével is foglalkozik a szerzô, mint Srí Lanka (Ceylon), valamint Thaiföld (Sziám), illetve Tajvan (Kínai Köztársaság). Hamza, 2002:76-77, 83-85, 87-88, 119-120, 131-132, 146-147, 152-156, 160-161, 189-191, 197-198, 222-223, 242-243, 253-258, 264-267, 276-279, 285-286, 291.

8 A jogi kultúrák pozicionáltsága vonatkozásában lásd a soron következố munkákat: Varga, 1992; 2006; Varga-Gessner-Hoeland, 1996.

9 A 20. század elejének a bécsi Pazmaneum mint teológiai fakultáson belüli oktatásmódszereinek személyesen megélt példájához (különös tekintettel a legjobbak számára sem egyszerúen érthetổ latin nyelvú - és német magyarázatokkal kísért - prelegáláshoz, illetve a héber, az arab, a perzsa és az egyéb keleti nyelvek tanulása során jelentkezô nehézségek átéléséhez) lásd Óriás Nándor (1886-1992) római jogász, teológus, latin-történelem szakos bölcsész emlékiratainak releváns passzusait.

10 Lásd az alábbi linken: http://www.ecls.eu/ (Letöltés: 2017. augusztus 10.). 


\section{Iván Dániel - Koi Gyula: Állam és jog az ellentétek földjén I.}

11 Mahler Ede orientalista (elsősorban egyiptológus), régész, az MTA levelezó tagja volt.

12 Kmoskó Mihály orientalista (Sumer, Egyiptom, szír kereszténység), vallástörténész (Ószövetség), az MTA levelezố tagja volt.

13 Goldziher Ignác orientalista, iszlám és sémi vallástörténettel foglalkozott. Az MTA rendes tagsága mellett nyolc külföldi akadémia tagja, két külhoni egyetem díszdoktora.

14 Étienne Balázs orientalista, a sinológia gazdaság- és jogtörténeti vetületeinek kutatója. Lásd jogi tárgyú múvei közül Balázs, 1954. A szerzô a kínai közigazgatás-, bürokrácia-, jog- és gazdaságtörténet múvelôje volt, aki e tárgykörökben angol, francia, valamint német nyelven írt monográfiákat alkotott (és élt is ezeken a nyelvterületeken Stefan Balázs, illetve Étienne Balázs neveken jegyezve munkáit). Német földön nyerve el képesítését, a párizsi Sorbonne professzora lett. Fenti múve a pinjin átírással Suishu néven ismeretes, a Sui-dinasztia (581-617) történetérôl szóló munka jogi vonatkozásait elemzi. A kínai történeti mú 25. könyve (fejezete) foglalkozott a büntetések és a jog kérdéseivel. Leginkább nem is a Sui-dinasztia, mint inkább a Song-dinasztia (907-1125), azaz a kínai ezüstkor problémáival foglalatoskodott. Legfontosabb monográfiái az alábbiak: Balázs, 1964; 1968. Doktori értekezését német nyelven írta a Tang-kori (617-907) gazdaságtörténetrôl: Balázs, 1931-1933. A Heydt-féle gyújtemény darabjainak kínai feliratairól lásd Balázs, 1934. Értékes tanulmányaiból megjelent magyar nyelvú fordításkötet Balázs, 1976.

15 László Ladany orientalista, sinológus, jogász, zenemúvész, Hongkongban tevékenykedô antimaoista jezsuita szerzetes, aki a China News Analysis szerkesztőjeként (1953-1983) igyekezett, hogy a kommunista Kína valóságát feltárja.

16 „3. $\$$ Secus esset, si capitula vel conventus, aut judices ordinarii scienter et studiose id facerent, vel aliter falsas et iniquas literas conficerent. Nam hoc modo tanquam falsarii et perjuri punientur; et ex eo capitula, vel conventus in sigillorum; praeterea illi, qui de membro capituli aut conventus, tempore confectionis et sigillationis hujusmodi falsarum literarum praesentes fuerint, in beneficiorum suorum; judices vero ordinarii seculares in sententiae capitali, nec non perpetua bonorum et jurium possessionariorum suorum, ipsos proprie concernentium, ac sigillorum pariter et honoris eorum amissione condemnantur.” Werbốczy, 1897:274. Partis II. Titulus 16. Super privilegiis cum clausula: De cujus, vel quorum notitia, confectis: Et de larvis, seu fictitiis personis. „3. § Másképp állana a dolog, hogyha a káptalanok vagy konventek avagy a rendes bírák ezt tudva [ti. az álarcos és színlelt személyek eljárást értve - I. D. és $K$. Gy.] és készakarva cselekednék vagy különben hamis és törvénytelen leveleket készítenének; mert ez esetben mint hamisítókat és hitszegôket kell büntetni óket; és ennélfogva a káptalanok vagy konventek az ô pecsétjüknek; azonkívül mindazok, akik a káptalan vagy konvent tagjai közül, az ilyen hamis levelek készítése és megpecsételése alkalmával jelen voltak javadalmaiknak; a világi rendes bírák pedig fóben járó ítélettel [azaz fôvesztéssel /decapitatio/ - I. D. és K. Gy.] és minden sajátul óket illetô fekvô jószágaiknak [azaz ingatlanaiknak - I. D. és $K$. Gy.] és birtokjogaiknak, valamint pecsétüknek és hivataluknak örökös elvesztésével lakolnak.” Werbő́czy, 1897:275. II. rész 16. cím. Azokról a kiváltságokról, amelyek „de cujus, vel quorum notitia” záradékkal készültek az álarcokról vagy színlelt személyekrôl. „3. $\S$ Secus est, si capitula vel conventus, aut judices ordinarii scienter et studiose id facerent, vel aliter falsas et iniquas literas conficerent. Nam hoc modo tanquam falsarii et perjuri punientur; et ex eo capitula, vel conventus in sigillorum; praeterea illi, qui de membro capituli aut conventus, tempore confectionis et sigillationis hujusmodi falsarum literarum praesentes fuerint, in beneficiorum suorum; judices vero ordinarii seculares in sententiae capitali, nec non perpetua bonorum et jurium possessionariorum suorum, ipsos proprie concernentium, ac sigillorum pariter et honoris eorum amissione condemnantur." Werbốczy, 1894:338. Partis II. Titulus 16. Super privilegiis cum clausula: De cujus, vel quorum notitia, confectis. Et de larvis, seu fictitiis personis. „3. § Másképpen áll a dolog, ha a káptalan vagy konvent, avagy az országos nagybírák (!) tudva és szándékosan tennék azt [ti. az álarcos és színlelt személyek eljárást értve - I. D. és $K$. Gy.] vagy egyébképpen hamis és törvénytelen okleveleket készítenének. Mert ez esetben mint hamisítók és hitszegốk fognak bûnhôdni; tehát a káptalanok vagy konventek pecsétjöknek; azok meg, akik a káptalan vagy konvent tagjai közül az efféle hamis oklevél készítésekor és megpecsételésekor jelen voltak, javadalmaiknak; a világi rendú országos nagybírák végül fejöknek, valamint az ôket tulajdonul illetô javaik és jószágaiknak, nem különben pecsétjök és becsületöknek örökre való elvesztésére ítéltetnek.” Werbóczy, 1894:339. II. rész 16. cím. Az ilyen záradékú kiváltságokról: Amelyeknek vagy 


\section{Polgári Szemle · 13. évfolyam 4-6. szám}

melyeknek tudomásáról. És az álarcokról, vagy színlelt személyekrôl. A szöveg megállapításához a két, forgalomban lévố legjobbnak tartott fordítást használtuk fel, és érdekes látni azt a nem jelentéktelen különbséget, mely szerint az álorcás vagy színlelt, azaz magukat másnak kiadó személyek, Kolosvári és Óvári szerint esetenként az ország rendes bíráival karöltve, míg Csiky szerint azonban csupán az ország nagybíráival összejátszva, követhetik el a cselekményt. Nyilván ez két meglehetôsen különbözô bírói kört érint, hiszen a rendes bírák közé kell számítani valamennyi ítélóbírót, míg nagybírákon (lat. judices regni ordinarii) a középkori magyar igazságszolgáltatás legfőbb bíráit értették, nevezetesen: a nádorispánt, az országbírót, a kancellárt (illetve a kancellár helyett késôbb a személynököt), valamint a tárnokmestert, addig az idôszakig, amíg a királyi kúriához tartozott. A problémát fokozza, hogy a rendes bíró (lat. judex ordinarius) kifejezésen azokat értették, akik a saját hatalmuknál fogva voltak bírók, ilyen volt: a király, a nádor, az országbíró, a személynök, a vajda, a bán, a fơispán, az alispán, a szolgabíró, a városbíró (a szabad királyi városban), illetve ezek helyettesei, illetôleg a földesúr, valamint a kánonjog szabályai szerint a pápa, az érsek megyéspüspök. Pomogyi, 2008:796, 1004. Az eredeti forrás latin szóhasználata judices ordinarii, azaz a rendes bírákra utal, vagyis a nagybíráknál tágabb személyi kört foglal magában, de olyan módon, hogy ebben a halmazban maguk a nagybírák is benne találhatóak.

17 A mártírakta (vértanúakta) meghatározás szerint: az ókeresztény kori vértanúk perérôl, elítélésérôl és kivégzéséról szóló beszámoló. Fajtái: történeti mártírakta: hiteles kortársak által írt bírósági jegyzőkönyv, illetve szemtanú beszámolója; a történeti mártírakta az elôzố típus átdolgozott és kibốvített formája: a scili vértanúk mártíraktáját példának okáért hétszer dolgozták át; legendás mártírakta: többnyire csekély történeti értékú, épületes vallási elbeszélések. Olykor maga az elbeszélés fôszereplôje is költött személy, mint Barlaám és Jozafát története esetében, amely az indiai Buddha-legenda vándormotívumát hordozza. Diós-Viczián XIV., 2004. A szír mártírakták (a mártírok perének jegyzôkönyvei) kiadására lásd Hoffmann, 1880; Braun, 1915. Érdekes párhuzam, hogy a római katolikusok egyes mártíraktákat latin fordításban már a 18. század második felében kiadtak hazánkban is, fóként Szent Jusztinusz (103-166), Szent Iréneusz (115/150-202/203) esetében, míg Antiochiai Szent Theophilosz (?-183), illetôleg Minucius Felix (?-250) szintén ismert volt. Szent Jusztinusz és Szent Iréneusz életére lásd Prileszky, 1765a; 1765b; Diós, 1984:237-241, 302-306, továbbá Antiochiai Szent Theophilosz életére lásd Zeegers, 1998:135-176; illetôleg Minucius Felix életére lásd Fredouille, 2005:525-528; Frenschkowski, 1993:1564-1567; Prileszky, 1764.

18 „Az isteni jog megismerésének forrásai a Szentírás könyvei, valamint a szent hagyományt tanúsító dokumentumok, különösen az egyházi tanítóhivatal (Magisterium) megnyilatkozásai. ” Erdő, 2014:86.

19, ,[H] uius studii duae sunt positiones: publicum et privatum. Publicum ius est, quod ad statum rei Romanae spectat, privatum, quod ad singulorum ultilatem; sunt enim quaedam publice utilia, quaedam privatim.” „[E] tudománynak két fő része van: a közjog és a magánjog. A közjog az [a jog], amely a római államra vonatkozik, a magánjog az, amely az egyének érdekét tartja szem elôtt; egyes dolgok ugyanis a köz hasznát szolgálják, mások a magánszemélyekét.” Ilyen értelemben tehát forrásszerú kifejezéssel nyilván nem lehetséges római alkotmányjogról, római büntetôjogról, római közigazgatási jogról, de még önálló római eljárásjogokról sem beszélni, hiszen mindezeket a ius publicum vagy a ius privatum kategóriáiba sorolták be, amelyek azonban nem azonosak sem a modern közjoggal, sem pedig a modern magánjoggal. Fontos arra is utalni, hogy részben téves az a közkeletû megközelítés, amely ezt a citátumot akként interpretálja, mintha elsôsorban a római jogági felosztásra vonatkoznék, hiszen nem szabad megfeledkeznünk arról, hogy az idézet második szava a tudományra (a stúdiumokra), azaz a jogtudományra (illetôleg a jogra mint tantárgyra) vonatkozik, így Ulpianus nem annyira a római jogrendszer tagozódásáról beszél, mint inkább a római jog tudományát dichotomizálja.

20 A kánonjogban a hitehagyás, valamint az eretnekség és a szakadárság fogalmát a 751. kánon határozza meg, ezen cselekmények büntetése önmagától beálló kiközösítés. Erdô, 2014:645-646.

21 A hanafita rítus egyiptomi ágának waqf felfogásához lásd az alábbi francia nyelvú kézikönyvet: AddaGhalioungui, 1893. 


\section{Iván Dániel - Koi Gyula: Állam és jog az ellentétek földjén I.}

\section{FELHASZNÁLT IRODALOM}

Adda, Benoit - Ghalioungui, Elias D. (trad.) (1893): Droit musulman. Le Wakf ou immobilisation d'aprés les principes du rite Hanafite. Traduit de l'arabe. Farag Haim Mizrahi, Alexandrie.

Balázs, Stefan (1931-1933): Beiträge zur Wirtschaftsgeschichte der Tang-Zeit (618-906). Mitteilungen des Seminars für Orientalische Sprachen, Jg. 34, No. 1, 1-92; Jg. 35, No. 1, 1-73, Jg. 36, No. 1, 1-62.

Balázs, Stefan (1934): Die Inschriften der Sammlung Baron Eduard von der Heydt. Walter de Gruyter, Berlin.

Balázs, Étienne (1954): Le traité juridique de Souei-chou. E. J. Brill, Leiden.

Balázs, Étienne (1964): Chinese Civilization and Bureaucracy. Variation on a Theme. Transl. J. M. Wright, Yale University, New Heaven.

Balázs, Étienne (1968): La bureaucratie céleste. Recherches sur l'économie et la société de la Chine traditionnelle. Gallimard, Paris. (A 12. és 13. fejezetet angolból Charles Leclus fordította franciára.)

Balázs, Étienne (1976): Gazdaság és társadalom a régi Kínában. Angolból és franciából ford. Ecsedy Ildikó, Európa Könyvkiadó, Budapest.

Braun, Oskar (1915): Ausgewählte Akten Persischer Märtyrer. Kempten, München.

Carr, Brian - Mahalingam, Indira (eds.) (2000): Companion Encyclopedia of Asian Philosophy. Routledge, London.

Coing, Helmut (1985): Europäisches Privatrecht I. Älteres Gemeines Recht, 1500 bis 1800 . C. H. Beck, München.

Coing, Helmut (1989): Europäisches Privatrecht II.19. Jahrhundert 1800-1914. C. H. Beck, München.

Concha Gyôzô (1871): Der Rechtsstaat. Eine publicistische Skizze von Dr. O. Bähr. Obelappelationsrath in Cassel. [Otto Bähr: Der Rechtsstaat. Eine publicistische Skizze, Cassel-Göttingen, 1864, Wigand.] Jog- és Államtudományi Folyóirat, 1. évf., 2. sz., 373-397.

Concha Gyốzô (1876): Néhány szó Grünwald Béla „Közigazgatásunk és a szabadság” czímú röpiratához. Tettey Nándor-Demjén Imre, Budapest-Kolozsvár.

Concha Gyôzô (1891): Magyarország és Ausztria közjogi viszonya történeti kifejlődésében és jelen alakjában. Írta dr. Polner Ödön budapesti kir. törvényszéki joggyakornok. A budapesti m. kir. tud. egyetemen 200 frt. pályadíjjal jutalmazott munka. Budapest, 1891. [Polner Ödön: Magyarország és Ausztria közjogi viszonya. Budapest, 1891, Singer és Wolfner.] Magyar Igazságügy, 17. évf., 3. sz., 198-264.

Concha Gyốzô (1892): Közjog és magyar közjog. Viszonválasz Nagy Ernoonek. Magyar Igazságügy, 18. évf., 1. sz., 46-113.

Concha Gyốzô (1895): A háború. A világbéke. In: Concha Gyốzô: Politika I. Alkotmánytan. Grill, Budapest, 89-92.

Concha Gyôzoo (1908): Báró Eötvös József és a külföldi kritika I-III. Budapesti Szemle, 51. évf. 377-379. sz., 187-212., 374-391., 91-113.

Derrett, J. Duncan M. (1968): Religion, Law and the State of India. Oxford University Press, Calcutta-Delhi.

Diós István (szerk.) (1984): A szentek élete. Szent István Társulat, Budapest, 1984.

Diós István (fôszerk.) - Viczián János (szerk.) (2004): Magyar katolikus lexikon XIV. Szent István Társulat, Budapest, 2004, http://lexikon.katolikus.hu/V/v\%C3\%A9rtan\%C3\%BAakta.html.

Driver, Godfrey R. - Miles, John C. (1952-1955): The Babylonian Laws I-II. Clarendon Press, Oxford.

Erdô Péter (2014): Egyházjog. Átdolg. Szuromi Szabolcs Anzelm, Szent István Társulat, Budapest.

Földi András - Hamza Gábor (1996): A római jog története és institúciói. Nemzeti Tankönyvkiadó, Budapest.

Fredouille, Jean-Claude (2005): Minucius Felix. In: Dictionnaire des philosophes antiques IV. Éd. Richard Goulet, CNRS, Paris, 525-528.

Frenschkowski, Marco (1993): Minucius Felix, Marcus. In: Biographisch-Bibliographisches Kirchenlexikon V. Bautz, Herzberg, 1564-1567.

Glenn, H. Patrick (2000): Legal Traditions of the World. Sustainable Diversity in Law. Oxford University Press, Oxford.

Goldziher Ignác (1884): A muhameddán jogtudomány eredetérôl. MTA, Budapest.

Grotius, Hugo (1999): A háború és a béke jogáról. Ford. Brósz Róbert, Diósdi György, Haraszti György, Muraközi Gyula, Pallas Stúdió - Attraktor Kft., Budapest.

Grossi, Paolo (2010): Das Recht in der europäischen Geschichte. C. H. Beck Verlag, München. 


\section{Polgári Szemle · 13. évfolyam 4-6. szám}

Hamza Gábor (1998): Jogösszehasonlítás és az antik jogrendszerek. Közgazdasági és Jogi Könyvkiadó, Budapest. Hamza Gábor (2002): Az európai magánjog fejlôdése. A modern magánjogi rendszerek kialakulása a római jogi hagyományok alapján. Nemzeti Tankönyvkiadó, Budapest.

Herzog, Roman (1999): Feltételezések a korai államokról. In: Roman Herzog: Ôsi államok. A hatalomgyakorlás eredete és formái. Corvina, Budapest, 13-80.

Hoffmann, Georg (1880): Auszüge aus Syrischen Akten Persischer Märtyrer. Übersetzt und durch Untersuchungen zur historischen Topographie erläutert. Brockhaus, Leipzig.

Jany János (2000): A Szaszanida birodalom magánjogának rendszere és továbbélése a Közel-Keleten. Pázmány Péter Tudományegyetem Jog- és Államtudományi Kar, Budapest.

Jany János (2006): Klasszikus iszlám jog. Egy jogi kultúra természetrajza. Gondolat Kiadó, Budapest.

Jany János (2007): Mítosz és valóság: az igazságszolgáltatás szociológiája az iszlám, a zsidó és a zoroasztriánus jogban. Pázmány Péter Katolikus Egyetem, Budapest.

Jany János (2011): Sasanian Law. University of California, Irvine.

Jany János (2012): Judging in the Islamic, Jewish and Zoroastrian Legal Traditions. A Comparison of Theory and Practice. Ashgate, Farnham.

Jany János (2016a): Jogi kultúrák Ázsiában. Kultúrtörténet, jogtudomány, mindennapok. Typotex Kiadó, Budapest.

Jany János (2016b): Az iszlamizmus. Eszmetörténet és geopolitika. Typotex Kiadó, Budapest. 175.

Jany János - Ilosvai Gábor - Bölcskei János (szerk.) (2000): Médiajogi kézikönyv I. Osiris Kiadó, Budapest.

Kmoskó Mihály (ford.) (1911): Hammurapi törvényei. Erdélyi Múzeum Egyesület, Kolozsvár.

Kmoskó Mihály (1913): Az emberiség elsố irott szabadságlevele (UruKaGina lagashi király reformjai). MTA, Budapest.

Koi Gyula (2016): Hagyomány vagy változás? Gondolatok a Lenkovics Barnabás tiszteletére készült ünnepi kötetrôl. Polgári Szemle, 11. évf., 1-3. sz., 166-184.

Ladany, Laszlo (1992): Law and Legality in China. The Testament of a China Watcher. Ed. Jürgen Domes, MarieLuise Näth, Hurst \& Co., London.

Lingat, Robert (1973): The Classical Law of India. Oxford University Press, Oxford.

Mahler Ede (1906): Babylonia és Assyria. MTA, Budapest.

Maine, Henry Sumner (1997): Az ósi jog. Ford. Sárkány Mihály, Gondola 96, Budapest.

[Mao, Zedong] (1959): Mao Ce-tung 21 verse. Magvetố Könyvkiadó, Budapest.

McGreal, Ian P. (ed.) (1995): Great Thinkers of the Eastern World. The major thinkers and the philosophical and religious classics of China, India, Japan, Korea and the world of Islam. Harper Collins Publishers, New York.

Óriás Nándor (2006): Emlékeim töredékei. PTE ÁJK, Pécs.

Pomogyi László (összeáll.) (2008): Magyar alkotmány-és jogtörténeti kéziszótár. M-érték Kiadó, Budapest.

Prileszky János (1764): Acta et scripta sancti Theophili patriarchae Antiocheni et M. Minutii Felicis in summam redacta et proloquiis atque annotationibus illustrata. Jezsuita Akadémiai Nyomda, Nagyszombat.

Prileszky János (1765a): S. Irenaei, episcopus et martyris acta et scripta suo ordine digesta et annotationibus historicotheologicis illustrata. Jezsuita Akadémiai Nyomda, Kassa.

Prileszky János (1765b): Sancti Justini philosophi et martyris Acta et Scripta suo ordine Digesta et annotationibus historico theologicis illustrata. Jezsuita Akadémiai Nyomda, Kassa.

Schacht, Joseph (1950): The Origins of the Muhammadan Jurisprudence. Oxford University Press, Oxford.

Sulyok Gábor (2012): Lagas és Umma területi vitája. In: Il me semblait que j’étais moi-même ce dont parlait l'ouvrage. Liber amicorum Endre Ferenczy. Szerk. Boóc Ádám, Fekete Balázs, Patrocinium Kiadó, Budapest, 266-281.

Sulyok Gábor (2013): Lagas és Umma területi vitája. Jogtörténeti Szemle, 27. évf., 1. sz., 17-27.

Sulyok Gábor (2014): II. Ramses és III. Hattusilis szerzôdése az örök békérôl és testvériségrôl. Jog, Állam, Politika, 6. évf., 2. sz., 3-22.

Tamás András (1977): Bíró és társadalom. A jogtudat és a jogérvényesülés dialektikája. Közgazdasági és Jogi Könyvkiadó, Budapest.

Tamás, András (1980): Sudya i obsčestvo. Dialektika pavosoznanija i pravoprimenenija. Ford. V. G. Guszeva, Izdatelstvo Juridičeskaya Litertura, Moskva. 
Varga, Csaba (szerk.) (1992): Comparative Legal Cultures. Dartmouth Publishing, Aldershot. Varga Csaba (szerk.) (2006): Összehasonlító jogi kultúrák. Szent István Társulat, Budapest.

Varga, Csaba - Gessner, Volkmar - Hoeland, Armin (eds.) (1996): European Legal Cultures. Dartmouth Publishing, Aldershot.

Vámbéry Ármin (1885): A török faj. MTA, Budapest.

Werbốczy István (1894): Tripartitum opus juris consuetudinarii Regni Hungariae. Magyarország szokásos jogának Hármaskönyve. Az eredeti kiadás magyar szövegét közölte, magyarra fordította, jegyzetekkel és a mú történetének megírásával kísérte Csiky Kálmán. Egyetemi Nyomda, Budapest.

Werbốczy István (1897): Hármaskönyve. Az eredetinek 1517-iki elsố kiadása után fordították, bevezetéssel és utalásokkal ellátták Kolosvári Sándor és Óvári Kelemen. Magyarázó jegyzetekkel kíséri Márkus Dezsô. Franklin Társulat, Budapest.

Wesel, Uwe (2010): Geschichte des Rechts in Europa. C. H. Beck, München, 2010.

Zeegers, Nicole (1998): Les trois cultures de Théophile d'Antioche. In: Les Apologistes chrétiens et la culture grecque. Éds. Joseph Doré, Bernard Pouderon, Beauchesne, Paris, 135-176. 